\title{
Back to the Future: The Landscape of the Financial Services Industry 2020 and Beyond
}

\author{
Brian D. Fitzpatrick ${ }^{1 *}$, John Reichmeier ${ }^{2}$, and Jacob Dowell ${ }^{3}$ \\ ${ }^{1}$ Professor of Finance, Rockhurst University, Kansas City, Missouri, USA \\ ${ }^{2}$ Rockhurst University, B.S.B.A., May 2016 \\ ${ }^{3}$ Rockhurst University, B.S.B.A., May 2016 \\ Email: Brian.Fitzpatrick@rockhurst.edu
}

\begin{abstract}
Investments in financial technology startups have more than tripled over the past five years and the debate has begun as to whether or not brick-and mortar banks will even exist in the future. (Skan, 2014) This paper will explore the emergence and evolution of cloud computing and its impact on investing. This new trend will incubate a new customer revolution which by the year 2020 and beyond will hatch and breed a new type of banking, saving and investing experience. Eventually, a complete shift will occur and technology will no longer be used to supplement financial advisors. Instead, advisors will be used as a supplementary resource for new technological models. Privacy concerns as well as applicable federal law will also be addressed.
\end{abstract}

Keywords: Technological models, financial services companies, emerging technologies, facial recognition technology

\section{The Evolving Consumer Demographic}

Before exploring the technologies that are impacting the financial service industry, we believe it is critically important to analyze the changes occurring in today's consumer demographic. A changing demographic will result in new standards, demands and expectations for this industry and advisors will have to adjust their products and services to entice the new demographic. Women currently control a majority of the world's personal wealth with $51.3 \%$, and are expected to receive $70 \%$ of the wealth transfers from baby boomers. Another notable change is that the younger generations are becoming increasingly diverse along with an increase in social diversity, specifically with single-parent households and same-sex relationships. (Lynch, 2013) Financial services companies could greatly benefit from using technology and social media to market to the growing demographic of women and minorities, especially with the substantial inheritance that women are expected to receive. That being said, the most significant demographical change for advisors to address will be age, and how to appeal to the technology-loving younger generations. In 2015, the oldest baby boomers will be turning 69 years old and the youngest will be 65 by 2029. The figure below illustrates that by 2020, there will be a significant increase of nearly 20 million people over the age of 60. (U.S. Bureau of the Census Special Reports: Population $60+$ by Age:1900-2050) This statistic has two very important implications for financial advisors. First, advisors will need to shift some of their focuses to retirement planning for their baby boomer clients. The second consequence is the intergenerational transfer of wealth that will occur as baby boomers pass their earnings down to the younger generations.

Rothstein Kass found that $86 \%$ of heirs in global family offices intend to fire their parent's financial advisor once they inherited their wealth. (Kuykendall, 2011) As a result, it becomes essential for advisors to not only attempt to secure new younger clients, but also to somehow appeal to their current client's beneficiaries. This task will prove to be increasingly difficult as millennials mature with a distrust in the financial services industry. The Harris Reputation Quotient currently ranks financial services as the third least trusted industry in the country, behind only the tobacco industry and the government.(Lynch, 2013) With the Recession of 2008-09, the scandals, and the lack of regulation in the industry, it is understandable that many people place a greater trust in technology than in financial advisors. This is a key reason for the recent surge in financial technology, and the authors believe it will 
result in a large self-service movement over the next few years.

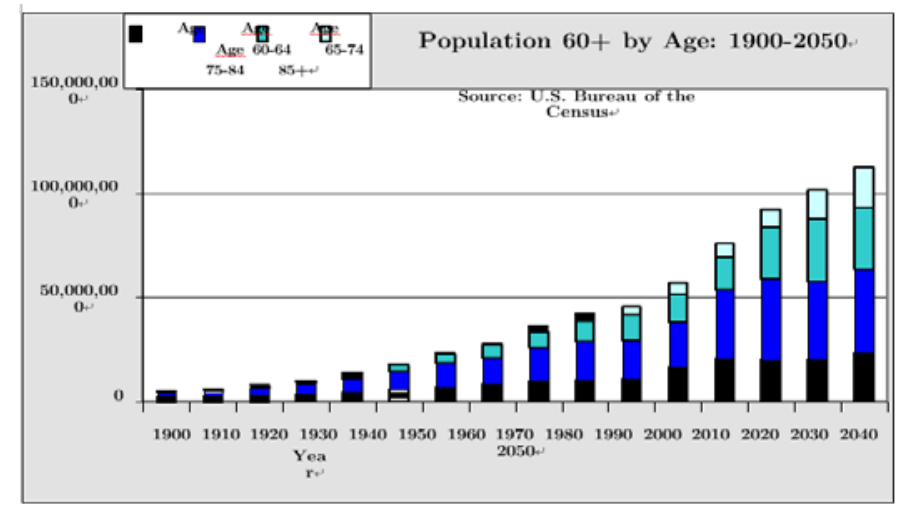

Figure1. Population $60+$ by age: 1900-2050, U.S. Bureau of the Census 2000

As a new, younger class of investors are entering the market, they bring with them new goals for their personal portfolios and new demands from the financial services industry. Future consumers will not seek an advisor who makes decisions on their behalf, but rather a company that provides the tools for clients to perform their own research and analytics, in order to make better informed investment decisions. Clients will want to receive information faster, cheaper, and especially with greater transparency. The lack of transparency between clients and advisors is a critical reason for the lack of trust in the industry, and it must be improved if advisors wish to obtain new clients. Consumers are now demanding more transparency with fees and charges from their advisors, as well as the risk/reward trade-offs with their potential investments. Clients will want user friendly tools and models that will clearly state if they invest in $\mathrm{X}$, the potential risks will be $\mathrm{Y}$ and the potential rewards will be Z. They will no longer want to schedule an appointment and have to drive to meet their advisors whenever they seek financial advice. The younger generations are being raised with an "I want it, and I want it now," mentality, which is why technological innovation is so imperative. Emerging technologies will enable consumers to receive information almost instantaneously and will empower users to effortlessly compute sophisticated calculations, thus hopefully improving the quality of their investments. In an era where one in five people own a smartphone and nearly everyone knows how to operate them, it is clear that technological advancements will be essential for the future success of the financial services industry.

\section{$2 \quad$ Saving and Investing}

The decision to save can be one of the most important financial decisions an individual can make. Whether someone is saving for a new car, investing for their child's college education, or saving for retirement, the process can be intimidating and confusing. Questions of how to save money, how much to save, and how to invest are frequently asked. The biggest barriers to saving are high expenses, low income, lack of time, and lack of information (Philios). Investment services often cost more than what people are able or willing to pay. This leaves individuals to find less expensive alternatives for advice such as asking friends and family, reading internet articles, or listening to news pundits. Pieces of advice through these less expensive mediums could help, but it does not create an overall savings or investing plan. Professional advisers and planners can help personalize plans that make sense for individuals.

Over the past several decades personal savings have dropped significantly in the United States. Figure 2 shows the change in personal savings as a percentage of disposable income. Savings, as defined by the Bureau of Economic Analysis, is the portion of personal income that is left over after taxes, and personal consumption expenses. This excess money can be used to save, invest, or hold cash. In 1985, Americans were saving $8.2 \%$ of their disposable income. By 2005 savings were at their lowest at $1.5 \%$, and by 2010 they were back to $6.2 \%$ (BEA, Alt., 2014). Taking a look at net savings as a percent of gross national income (GNI) tells a slightly different story, as seen in Figure 3. It accounts for savings of total income as opposed to disposable income. In 1965 net savings was $12.7 \%$ of GNI, and gradually decreased to - 
$2.0 \%$ in 2009. By the end of 2013 it was back up to $2.4 \%$ (BEA, GNI). With a GNI per capita of about $\$ 54,000$, this translates to roughly $\$ 1,300$ per person (The World Bank Group, 2014).

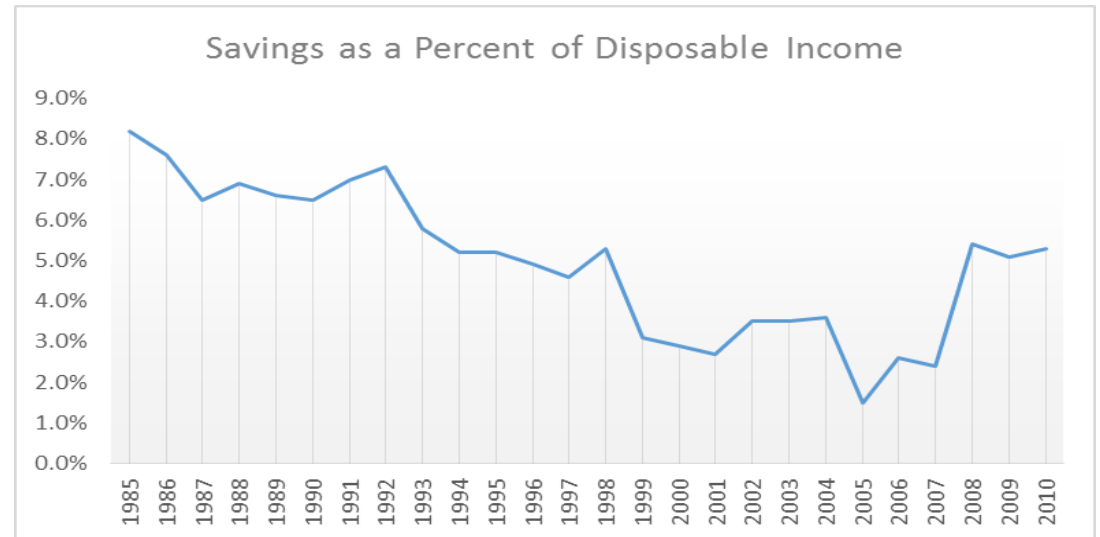

*This chart is a recreation of a chart created by the Bureau of Economic Anaylsys, 2014

Figure 2. Change in personal savings as a percentage of disposable income

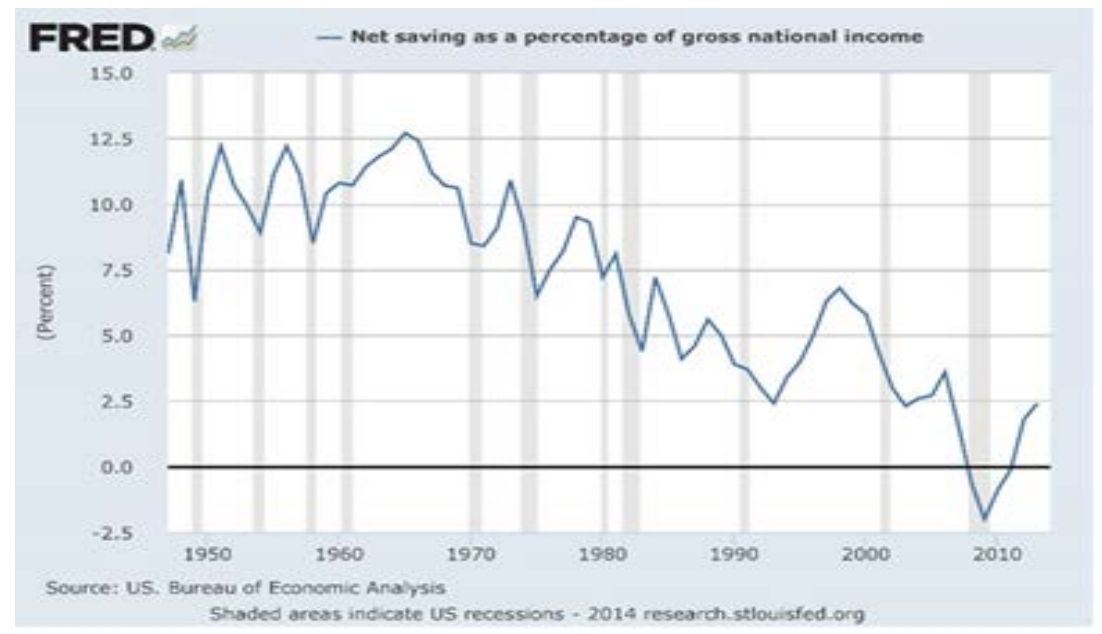

*U.S. Bureau of Economic Analysis

Figure 3: Savings of total income as opposed to disposable income

Looking at savings from both disposable income and GNI approaches, we see that the trend has been declining. With a bounce-back in savings rates following the Great Recession, individuals are more aware of the importance of saving and investing. As the landscape of financial services continues to change, questions of how to save and invest get even more complicated. Having credible information from financial professionals can help boost expectations about savings and investing goals. However, the recent financial collapse has left a dark shadow on the industry. Banks have had to regain the trust of consumers while adapting to new regulations. PricewaterhouseCoopers estimates that a new mass of affluent Generation Xers (born between 1964 and 1983), have $\$ 7.5$ trillion in assets (Hyde, Jain and Lyman, 2013).

\section{$3 \quad$ The Technological Disruptions}

"Rather than a mere commodity, data is increasingly viewed as the invaluable business asset it truly is. The reason for this significant shift in perception is that new technological innovations are empowering us to slice, dice, process, manage and correlate data in ways that give it exponentially greater value in the eyes of our clients, allowing them to make more informed investment decisions than ever before." (Donohue, 2014) This quote from State Street's Chief Information Officer perfectly illustrates how 
technology is changing the way in which people perceive and utilize data to make investment decisions. The technological phenomenon of cloud computing will revolutionize the way in which both advisors and individual investors will compute and share data. But what exactly is cloud computing? Cloud computing is the storing and accessing of data and programs over the internet rather than on a computer's local hard drive. The cloud allows users to access and share their data wherever and whenever they want. With the push of a button, a user can instantaneously share and synchronize his or her data with other investors, enabling faster and more efficient peer-to-peer collaboration.

Although cloud computing is not new, and has been successfully implemented into several industries already, it is just now starting to breach the financial services industry. Cloud computing can fulfill the consumers' desire to receive information both quickly and cheaply, in addition to providing more detailed and accurate results. Volume VIII from State Street's Vision explains how operating in a cloud environment will present clients with a broad range of benefits. For example, cloud computing can provide automation and capacity on demand, an accelerated time to market, and improved client services. Cloud environments also offer advanced platforms for product and service innovations such as custom analytics, risk control and advisory services. Financial service companies that utilize the cloud will be able to provide new products and optimal customer service for their clients. Consumers will have the freedom to check their portfolios from anywhere in the world as long as there is an internet connection. The cloud will provide a new alternative option for consumers seeking financial advice.

Advisors will be able to use the cloud to compute practically an infinite number of investment scenarios that they could upload and immediately send to their clients. Once the cloud is fully integrated into the financial services industry, clients will benefit from improvements in transparency, accessibility, and security of their data as well as better communication with their advisors.

Finance companies perceive converting to cloud computing as one of the top three most important future initiatives for their business. (Gartner, 2013) By 2020, the majority of financial service companies will have transposed their data to the cloud, which will not only reduce the cost of data storage, but also provide the firms with a competitive advantage over the companies using an on premise server.

As previously stated, financial service companies will have to adjust their services and product offerings in order to fulfill the demands of the millennials. The purchasing power of the millennials is growing, making it increasingly important for companies to take advantage of this market. In our opinion, the best method to attract millennials will be for financial institutions to make their product offerings more easily accessible through the use of smartphones. Smartphones play a critical role in the lives of this generation and the number of people who own them is steadily increasing. A study by Zogby Analytics explains that $87 \%$ of people said that their cell phone never leaves their side and $80 \%$ said that checking their cell phone is the first thing they do every morning. As smartphone technology continues to improve, customers are becoming more reliant on their devices to perform countless different processes. Nearly $60 \%$ of millennials believe that in the next five years, everything will be done on mobile devices. (Reichert, 2014) Financial service companies need to utilize the technological innovations on mobile devices to provide their customers with the mobility and convenience that they desire. Several banks are already using this technology for mobile banking, but one in three millennials wish that the industry would adopt more mobile imaging functionality. Bank of America currently has one of the most advanced mobile banking platforms in the industry. Customers have the ability to deposit checks straight into their account simply by snapping a photograph of the front and the back of a check. In addition, the bank offers a feature that allows people to make payments without a debit or credit card, simply by scanning the card image from a smartphone. James B. DeBello, the president and CEO of Mitek said, "Business and banks especially need to offer or enhance their mobile capabilities for picture- based communication if they are going to remain relevant. Millennials and their mobile device cameras will ultimately change commerce from the written word, to a picture-based experience." (Reichert, 2014) Smartphone capabilities and the camera function are changing the way people bank, and as the technology advances further, customers will no longer need to carry cash or a credit card as long as they have their smartphone on hand.

Developing a mobile platform will be increasingly vital for financial advising companies. The younger generation routinely takes advantage of smartphone technology for research, transactions and bill paying, as well as an alternative option for seeking financial advice. There are hundreds of financial-related applications for smartphones that offer investment advice, portfolio tracking, financial needs calculating, and numerous other financial tools. IPhones have applications for Seeking Alpha, Yahoo Finance, Trade 
King and Loyal that investors use daily for research and to keep track of their portfolio. Smartphones enable investors to research and make trades anywhere they go, in addition to improving communication with advisors and other investors. Financial advisors use smartphones to review client accounts, prepare financial plans, and to stay highly connected with their clients. Mobile devices also provide advisors with the ability to enhance their workflow while off site.

Even though there has been a tremendous surge in mobile technology, we are still in the early stages of mobile use within the financial industry. In the years to come, there will be new devices and more integrated applications that will continue to advance the way in which consumers conduct financial decision making, and also will help financial institutions in better serving their clients. Financial services companies must take advantage of the fast-growing mobile technology sector to provide new, convenient services for their clients, and to appeal to the tech-savvy millennials.

The ringleader of financial technology startups is an application called Lending Club. Lending Club is a peer-to-peer online credit marketplace where investors back credit-worthy borrowers in exchange for interest income. The application uses a technology enabled matchmaker to link someone who is seeking a loan with a potential investor, thus eliminating the banks as middlemen. Customers fill out an application and then lending club evaluates the borrower, determines an interest rate and then presents a variety of offers to the investors. The online technology lowers the cost of credit and borrowers benefit from lower interest rates, while investors enjoy solid returns. (Lending Club, 2014) The company launched their initial public offering on December 11, 2014 and the stock price soared 58\% on the first day. The success of this IPO shows that people are enthusiastic and confident about the financial technology startup, and Lending Club is paving the way for future startups to enter the market. The company is transforming the banking system to make it more efficient, transparent and customerfriendly; in addition it is providing borrowers with an average savings of $30 \%$ on their interest costs.

Another fast-growing industry among the millennials is social media. Sites such as Facebook, Twitter and Instagram have become extremely popular and are used to connect with friends and to stay up to date with current events. New financial technology startups are attempting to bring the social media to the investment world. E-Toro is the world's leading social investing network that allows investors to connect with each other and discuss, trade, learn, and teach across the network. It allows users to watch the trade activity of other investors and ranks investors based on their number of followers. (E-Torro, 2014) Many people believe that "social trading" as they call it is the future of financial investing as sites like E-Toro connect investors from all over the world into one social network. Covester is an online investment management marketplace that connects users with over 100 portfolio managers and investment strategies. The site advertises low fees, exceptional security, and complete transparency (ETorro, 2014). The site offers instant connection to successful investors. (Covestor, 2014) Nearly 129 million trades have been conducted on this site and that number is rapidly increasing.

These are merely a few of examples of financial technology startups on the market today and there are numerous others in development. The startups are yet another opportunity for individual investors to receive excellent financial advice and services. The new technologies provide investors with an abundance of tools to become more successful investors, and the startups should certainly be a concern for banks and advising companies. The fact that investments in financial technology startups have tripled over the last five years indicates that entrepreneurs are working towards taking advantage of this changing consumer demographic by creating innovative applications that appeal to the tech- savvy millennials. The emergence of new cloud computing technology and advances in smartphone applications are changing the way consumers obtain and dissect information. Financial institutions must adjust their models in order to implement these innovations and provide a more advanced platform for the consumers. If financial advising companies can successfully integrate these new technologies into their business models, the effect of the many financial technology startups should be minimal on the future of this industry.

In general, cloud computing is an on-demand delivery service for computing resources. It is paid for as it is used, and it is accessed through the internet. (Mell and Grance, 2014) A firm can choose to be on a public cloud, a private cloud, a community cloud, or a hybrid. Three main types of cloud services are software as a service (SaaS), platform as a service (PaaS), and infrastructure as a service (IaaS). Tables 1 and 2 explain different cloud infrastructures and services. 
Table 1. Cloud Infrastructures

\begin{tabular}{|c|c|c|c|}
\hline Cloud & Exclusiveness & Location & Owned, managed, operated \\
\hline Public & General public & Vendor site & $\begin{array}{l}\text { A business, academic, or } \\
\text { government organization, or } \\
\text { a combination }\end{array}$ \\
\hline Private & Single organization & On or off-site & $\begin{array}{l}\text { The organization, a third } \\
\text { party, or a combination }\end{array}$ \\
\hline Community & Specific organizations & On or off-site & $\begin{array}{l}\text { One or more organizations, } \\
\text { a third party, or a } \\
\text { combination }\end{array}$ \\
\hline Hybrid & $\begin{array}{l}\text { Combination of two or } \\
\text { more infrastructures }\end{array}$ & On or off-site & $\begin{array}{l}\text { One or more organizations, } \\
\text { a third party, or a } \\
\text { combination }\end{array}$ \\
\hline
\end{tabular}

Table 2. Cloud Services

\begin{tabular}{ll}
\hline Service & Description \\
\hline SaaS & Cloud-based applications that are available from various client devices \\
PaaS & $\begin{array}{l}\text { Provides a cloud-based environment to support building and delivering } \\
\text { web-based applications }\end{array}$ \\
laaS & $\begin{array}{l}\text { Provides companies with servers, networking, storage, and data center } \\
\text { space }\end{array}$ \\
\hline
\end{tabular}

*Source: National Institute of Standards and Technology 2014

According to a survey conducted in September 2014 by SAP and analyst firm Ovum, the outlook for cloud technology is very optimistic. Some key highlights from the study found that half of business decision makers foresee increased spending in the next 18 months on SaaS; 80\% of IT decision makers view SaaS as enabling rapid response to market opportunities; and $79 \%$ agree that SaaS makes it easier for new entrants to the market (SAP News, 2014). Clearly there is an emphasis on transitioning to and increasing the usage of cloud technology.

There are multiple applications that could be converted to the cloud. Non-core applications and business processes such as recruiting, billing and travel management; infrastructure operations, such as data center management, data storage and disaster recovery could also be moved to the cloud. Other core solutions like batch processing, analytics, and reporting applications would also be good candidates (Garg, 2014).

There are some concerns about adapting to the cloud within the financial industry. Security, data privacy, disaster recovery, and regulatory compliance are some of the biggest issues facing the industry (Garg, 2014). These issues are not unique to the cloud computing. Companies with in-house infrastructure and software face many of the same obstacles in ensuring safety as a cloud vendor.

Company IT professionals will still have the task of thwarting hackers and ensuring their systems are up-to-date while responding to market opportunities. This is no different than using a cloud from a vendor. Efforts from groups like the Cloud Security Alliance are conducting research to better understand vulnerabilities of cloud technologies (Cloud Security Alliance, 2014). With better understanding of the risks involved and solutions to problems, security of sensitive data will continue to grow stronger.

\section{The Financial Advisors' Response}

Consumers will demand information in the future faster, cheaper, and with more transparency, which will be made possible with the advancements in cloud computing and smartphone applications. The millennials will have greater purchasing power in the future as well as a new set of demands from the financial services industry. This generation's obsession with technology, especially mobile phones, will spur even more financial technology startups and already, several companies have had success as their business models aim to replace the need for banks and personal advisers. So what can advisors possibly do to keep up with the changing environment and not be run out of the industry by technological 
advancements?

Advisors first must develop a strategy to help consumers overcome their distrust in the financial industry. Further implementation of the Dodd-Frank Act should increase consumer confidence, but advisors will still have a hefty task at hand to persuade the millennials. Going forward, we believe in the future advisors will place a greater focus on building long-lasting relationships and a better sense of trust with their clients. In order to do this, it is absolutely critical for advisors to create more transparency with their models so the clients are fully aware of the fees and the risks associated with their portfolio. It will become pivotal for advisors to sincerely get to know their clients. For example they should learn about the potential client's family plan, their occupations, current goals and retirement goals. This will help the advisors form better relationships with the clients as well as enable them to create a portfolio that is perfect for the client's expectations. Advisors should focus on building this relationship before ever mentioning management fees. In addition, advisors should eliminate or at least lower their minimum asset requirements so a greater number of people could have access to their services.

Financial advisors whose sole purpose is to gather assets to increase their management fees will not be successful in the future, and will most likely lose business to the online marketplace. However, advisors who build excellent client relationships and truly act in the best interest of their clients should continue to be successful. That being said, advisors will have to make several adjustments to respond to this new financial environment, otherwise someday they may be replaced by robots.

As illustrated below, Oxford University performed a study on the jobs that are most likely to be replaced by robots in the future. The study predicts that personal financial advisors have a $58 \%$ risk of being replaced by robotic advisors. (Peterson)

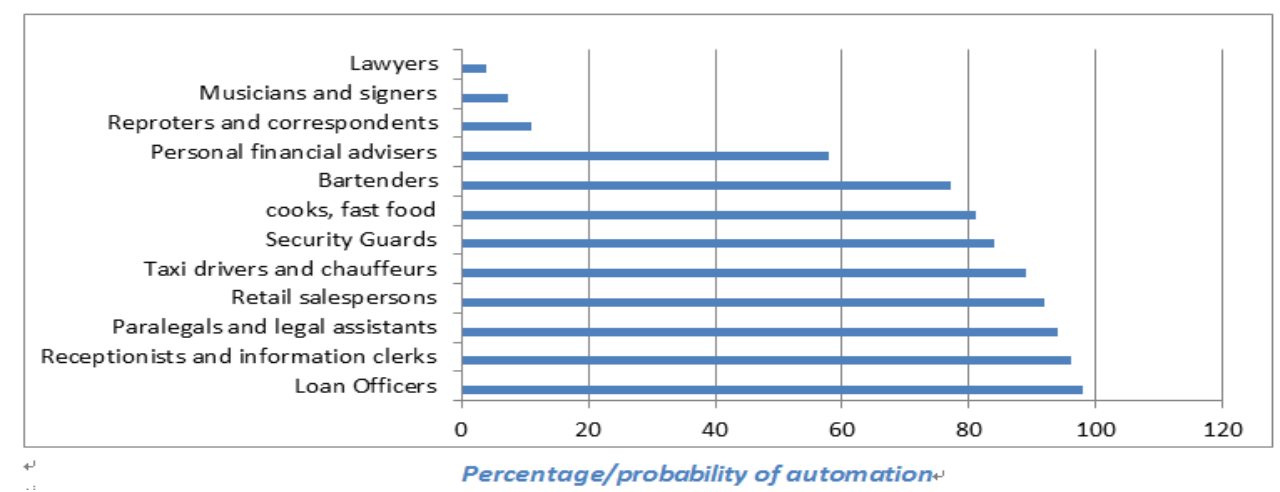

*Oxford University data via Bloomberg News, www.businessinsider.com

Figure 4: Jobs at risk of being replaced by robots, Oxford University via Business Insider 2015

We believe the best way for advisors not to be replaced by technology is to utilize these innovations to make their services more attractive to potential clients. We believe that in the future, someone who wishes to become a financial adviser will not only need a masterful knowledge of the investments industry, but also an exceptional understanding of the technology surrounding it. Advisors should take advantage of the advancements in cloud computing and smartphones to provide the faster and more transparent service that consumers are demanding. With these technologies, advisors can create a platform that allows their clients to instantly view their portfolio regardless of their location. By developing an exceptional understanding of cloud computing, advisors could send their clients a countless number of investment scenarios that could be accessible on any mobile device. The new model's integrated technology would also allow advisors to work and stay in touch with their clients, even when they are not in the office. It would improve communication tremendously and help the advisors with the ongoing process of maintaining relationships with their clients. Advisors could also take advantage of the high quality cameras in smartphones and tablets if a client wanted to meet faceto-face without driving to the advisor's office.

No longer will clients only see their advisor once a year and receive a detailed report on their portfolio that they could not possibly understand. The new model could vastly improve the communication and transparency between an advisor and his or her clients, and it will empower advisors to be an easily 
reachable asset to all of their clients. We believe that it will be essential for advisors to prove to their clients that they are a necessary asset, by providing value-added services to ensure the success of their portfolios. As customers will become more involved in their investment decisions, successful advisors will be those who do not try to control their clients' portfolios, but rather make themselves a valuable and always available resource whenever a client needs financial advice. It will also be very important for companies to embrace and develop new technology to provide their clients with tools and services that can provide more value to clients than these financial technology startups.

We do not honestly believe that robotic advisors will ever completely replace personal advisors. People enjoy the human connection and clients would feel more comfortable developing a sincere relationship with an advisor. In addition, personal advisors will always be better at explaining particular circumstances in ways that clients can understand, because not everyone who wishes to invest will be a finance expert. Advisors will also benefit from the fact that far too many Americans are inherently lazy and will not want to play a significant role in making their portfolio decisions. This is another reason why there will be a greater focus on building solid relationships because the people who do not wish to play an active role in their investments will seek an advisor that can truly be trusted with their financial decision-making. Therefore, while some people believe these technological innovations are a threat to the industry, we believe advisors should accept and embrace the technology and implement it into their service models to make them a more valuable asset for their clientele. If advisors can successfully implement this technology to improve their analytics and customer service, along with maintaining excellent client relationships, then the future could certainly be bright for the advising industry. Companies, who fail to integrate new technology into their business models, should witness people using virtual assistants like Siri on the IPhone for financial advice in the future. We have faith, however, that the financial institutions will get with the times and commence taking advantage of new technology in order to help this industry be more successful than ever before.

\section{$5 \quad$ A New Model}

Technology has allowed individuals to conduct online research through brokerage sites, blogs, and other news articles. Using those resources defers decision making away from professionals and into the hands of consumers. However, there was, and still is, a problem with that model. Even though people have resources to help them make better decisions with their money, they cannot always make sense of them. Average users do not have the expertise or the time to properly educate themselves on all of their financial and investing issues. Managing a financial portfolio, managing financial priorities, and managing a lifestyle to fit those concerns are not easy to accomplish alone. Thus, decisions will be based on partial or incorrect knowledge. This is why financial professionals are still around. In time with the increase in supply, competition ultimately will usher in lower pricing.

Utilizing advances in technology does have its advantages. Through cloud services - mobile applications on smartphones, tablets, and laptops make it more convenient than ever to manage money. However, there will be three main elements that help competition stand out from the crowd: education, affordability and customization. Education through customer service is the most important element that each business should offer. A recent survey conducted by consulting group Capgemini, found that positive experiences with customers are due to the trust they place in their banks. Adding a human element to help guide people through the technology, helps to build earned trust. So not only will a channel of online services need to be available, but there will also need to be real people to talk to. The roles of financial advisers will evolve from having face-to-face conversations to Skype interactions. Through cloud applications, advisers and consumers will be able to instantly connect, with both having access to the consumers' financial information.

A noticeable change is that these new businesses do not need a physical location because of a digital shift. Sites like LearnVest allow free services to manage multiple accounts, set and follow personal goals, and track personal expenses. They also have an option to buy a package which allows a real-life financial planner to help individuals and households set targets while keeping tabs on their goals with them. There are options to do this through mobile applications or actually speaking to professionals (LearnVest). The education process is the most important because only through education can people really commence taking control of their finances. 
Affordability will be a prerequisite for future generations of investors. Coming off the economic recession in 2008-09, many Americans want to stretch their money. They want to get the best services available while paying the least amount of money for them. Not only is it important for the services to be affordable, but the expenses must be transparent and predictable. Switching over to the cloud businesses will allow companies to compete for prices without sacrificing margins. As operating costs come down, cost savings can also be passed along to consumers. Expenses for consumers can also become more predictable because businesses can determine the average computing power they use, and pay for, with the cloud. Therefore, a flat fee can be charged to customers for them to have full access to their information whenever they need it without worrying about extra charges. New applications and websites comparable to Glassdoor will be available for consumers to compare prices, services, and overall satisfaction, thus creating more market competition.

The third element for businesses is customization. No two people have the same needs, goals, income, or lifestyle. Being able to cater to each person will satisfy these high demands. For example, if an investor wants to diversify his or her portfolio through mutual funds or ETFs, they are stuck with the stocks that are a part of that fund whether or not you like the particular stocks within the fund. Your only decision in that scenario is to either buy the fund or not. With an investing site like Motif, there is more flexibility and customization (Motif Investing). This site allows users to customize stocks and their weights within funds. The education of the individual user will still help dictate the returns earned. That is why Motif also has financial advisers available to talk to in order to come up with the best plans for each investor.

Public accounting firm KPMG categorized four underserved markets, ranging from those who do not use a bank to young adults with little knowledge about financial products. These markets, shown in Table 3 are: the unbanked, rebuilders, work-to-pay, and emerging retail. The unbanked are typically those that are recent immigrants, are hourly workers, prepay for most of their expenses, and only operate through cash or money orders. Rebuilders are those who have recently gone through negative events in their lives such as bankruptcy, divorce or unemployment. The recent events in their lives have depleted any savings they had, and now have limited access to credit cards. Work-to-pay markets are generally part-time workers with low credit scores. They mainly operate on cash and use payday loans for cash flow needs. The fourth category is emerging retail; these people are recent high school or trade school graduates and have limited access to liquidity. They have above normal interest rates, but they are diligent about paying bills on time and dedicated to savings goals. New and strategic approaches are needed to address these market niches. Banks also have an opportunity to establish customer loyalty by aiding them in their personal finances (KPMG, 2011).

These new models of saving and investing will benefit everyone regardless of income level. If an individual has savings goals, free sites like the aforementioned LearnVest are easy to use and can help visualize expenses. All they need is a bank account. The online bank simple.com is completely digital and users have access to 55,000 ATMs (The Bancorp Bank, 2014). If there is a need to talk to a financial planner, new methods will be available to reach certified professionals. Folks living in rural areas may not have the time to travel and meet with an adviser, but it will now be easier and more affordable thanks to the cloud.

\section{$6 \quad$ Financial Technology Startups}

Dietz, Khanna, Olanrewaju and Rajgopal (2016) state that financial technology is omnipresent; in fact globally, approximately $\$ 23$ billion of venture capital and growth equity has been distributed to FinTechs over the past five years, and this number is growing exponentially. These authors state that the present demographic shift is substantial. In the U.S. alone, some 85 million digital millennials are coming of age with more openness than 40 million GenXers who came of age during the dot-com boom and bubble. By 2025, the FinTechs will continue to force lower pricing and force margin compression. Dietz, Khanna, Olanrewaju and Raujopal believe that the new environment will be distinguished by six distinct characteristics: advantaged modes of customer acquisition; reductions in the cost to serve; innovative uses of data; segment-specific propositions; leveraging existing infrastructure; and managing risk and regulatory stakeholders. They believe that the ultimate test of whether a FinTech company will succeed or fail is whether the six characteristics will help create a new business model - similar to what 
inventory meant to Netflix and what storefronts meant to Amazon. It appears that banks will be the new dying dinosaurs.

Table 3. Four underserved markets

\begin{tabular}{|c|c|c|c|}
\hline Category & Age & Income & Description \\
\hline Unbanked & $18-40$ & $\$ 12,000-35,000$ & $\begin{array}{l}\text { - Hourly workers } \\
\text { - Prepay most expenses } \\
\text { - Cash }\end{array}$ \\
\hline Rebuilder & $30-55$ & $\$ 50,000-150,000$ & $\begin{array}{l}\text { - Recent negative event } \\
\text { - } \text { At least } 1 \text { checking account } \\
\text { - Lack savings } \\
\text { Limited credit }\end{array}$ \\
\hline Work-to-pay & $18-30$ & $\$ 18,000-40,000$ & $\begin{array}{ll}\text { - Hourly worker } \\
\text { - Low credit score } \\
\text { - Use payday loans } \\
\text { - Cash }\end{array}$ \\
\hline Emerging retail & $18-26$ & $\$ 25,000-60,000$ & $\begin{array}{l}\text { - Recent high school/trade } \\
\text { school graduate } \\
\text { - High interest rates } \\
\text { - Diligent about payments } \\
\text { and savings }\end{array}$ \\
\hline
\end{tabular}

*Source: KMPG Study 2011

Kappagantula and Kulkarni (2015) believe that the coming of visual technologies in union with artificial intelligence will pave the future with deciphering visually available data and this will create new vistas in computer-aided decision-making. The video analytics market is expected to grow from 2015 to 2020 at an estimated compound annual growth rate of $20.9 \%$. In addition, visual data discovery tool is estimated to grow $250 \%$ faster than the rest of the BI market. The future will bring better insights, as well as the ability to store more data at a cheaper cost. Investors will be able to make more accurate predictions, and they will be able to analyze much more data quicker. HSBC has already installed "facial-biometric access control units" in its data centers, and a Danbury, Connecticut based bank already implements facial-recognition technology as well as customer data analytics to help identify fraudulent individuals.

\section{$7 \quad$ Privacy Concerns}

Data breaches have appeared to be ubiquitous of late - from credit card companies to even the financial debacle at Target, Inc. Financial Services Firms can be particularly vulnerable especially when millennials want instant access, and they want it on their time frame. Solutions are varied, but one controversial but popular future move is to implement some type of facial recognition technology. Companies are presently using this information for predominately-marketing purposes, but government uses the technology to help combat terrorism.

The report, Facial Recognition Technology: Commercial Uses, Privacy Issues, and Applicable Federal Law, was given to the Subcommittee on privacy, Technology and the Law General Accountability Office in July 2015. There are various laws presently on the books, however many of these laws appear to be outdated. Many privacy advocates want more protection, but as recent breaches have proven, laws do not usually stop criminals from action. The Gramm-Leach-Bliley Act (GLBA-1999) was designed to restrict the disclosure of public information. The Fair Credit Reporting Act (1970) supposedly protects the security and confidentiality of personal information. Companies as well as consumers want more surveillance on the criminals. Will the future allow technology to block criminals or will privacy concerns rule the day?

In the GAO report in the summer of 2015, we entertain facial recognition technology (FRT) to block unwarranted users from entering financial services products. Although millennials may want to divulge personal information on Facebook, they have no desire to have their financial information or their money stolen. Most financial experts believe that in the future - and not that far away - it will be feasible to readily and accurately identify by name practically any individual in the world by implanting (FRT). The National Telecommunications and Information Administration (NTIA), a department of the Commerce agency, is presently addressing privacy issues associated with this technology. The NTIA is 
including convening stakeholders to try to develop a voluntary and enforceable code of conduct for industry participants. The GAO report in the summer of 2015, reviews privacy issues involving FRT. This report analyzed four areas of concern: the use of FRT, privacy issues concerning commercial uses of FRT, the proposed best practices and industry privacy policies for FRT, and any privacy protections under federal law that apply to FRT. Privacy concerns are relevant, but the major recent breaches of security including the Target, Inc. fiasco could have been averted with the use of FRT. (GAO Report)

Facial recognition technology (FRT) is one of many biometric technologies - eye scanning being even more effective - which identifies individuals by measuring and analyzing not only physiological characteristics but also behavioral tendencies. These biometric technologies have been created to help identify people analyzing their faces, hands, eye retinas and irises, fingerprints, voice and gait, etc. Conventional identification methods, as usernames, passwords or special cards for entry can dupe the old systems, but various biometric technologies measure distinctions, which are unique to each individual person and cannot be changed easily. (GAO Report,)

The GAO Report lists four basic components to an effective facial recognition technology system: obviously a camera, an algorithm to create a face print - called a facial template, databases to store images, and an algorithm to compare the image to the databases of images or a singular image in the main database. This technology is already here, but the public's concern is more with corporations using the information, as opposed to the government implementing the technology. The Homeland Security of the U.S. government already requires fingerprints to procure a TSA early boarding numbers for airline transportation use. When people, especially the millennials desire safety over privacy, then this technology of the future will be implemented across the board. We personally believe that Facial Recognition Technologies along with other biometric technologies is here to stay, and concerns should be more about companies sharing private data. Consumers can still opt out of allowing corporations permission to share personal information. Biometric Technologies are future resources, which probably will not ultimately be blocked by free but safe governments. The safety concerns in industries such as transportation and financial services are just too great. (GAO Report)

\section{Conclusion}

The future of financial decision making has met the newest round of emerging technologies. Dealing with the aftermath of the 2008 financial collapse, addressing issues within the financial industry today are more complex than they have ever been for this generation. The emergence of cloud computing is allowing firms to face these complexities. Affordable services, better education, and customization are three elements in which the cloud creates an advantage. The cloud allows businesses lower operating costs, higher customer service, and the ability to respond to new market opportunities at quicker rates. This new customer revolution will breed a new type of banking, saving, and investing experience. The convenience cloud computing brings, fosters an environment for consumers to check their savings goal via smartphone or tablet to make wiser financial decisions. The financial services industry will face many more disruptors in the future, but for now it is fine just to check your phone.

The manner in which the financial service industry handles the millennials and the massive intergenerational transfer of wealth will be essential to the future success of the industry. This changing consumer demographic has ignited a frenzy of changes in the form of technological advancements and financial technology startups. These innovations can either be detrimental to the industry or serve as a source for future stability, if the companies take advantage of technology and use it to better serve their clients. The use of cloud computing and the always improving smartphone technology can help individuals become better investors, as well as enable advisors to become more important assets to their clients. Investors in the future should consider technology, data and advisors as important assets to their financial success. It will become extremely important for advisors to demonstrate to both potential and current clients that they will put their personal interests aside, and truly do what is best for the clients. If advisors can achieve this and help to eliminate the significant distrust in the financial services industry, then the technological innovations will serve as a catalyst to propel the industry to new heights and successes. Financial technology startups are attempting to eliminate the need for banks and advisors, so the industry must continue to advance their own technology and provide services that are more valuable than computer applications. The successful implementation of new technology will improve the 
advisor-client relationships and will facilitate more efficient communication, analytics and value-added services. Consumers will benefit from the technological advancements because they will have more access to better information and it will be much more convenient for them to seek financial advice. More technology will disrupt the financial services industry in the future, and it will be pivotal for the industry to take advantage of the innovation to become more attractive for younger potential investors.

Bill Gates once said, "Technology is just a tool. In terms of getting the kids working together and motivating them, the teacher is most important." (Gates, 2014) This quote is applicable to the disruptive technologies that are changing the financial landscape because even with all of these spectacular innovations, what will always be most important will be the people - the investors. In this scenario, advisors will serve as the teachers, and the new consumer demographic will serve as the children. The financial advising companies should work tirelessly to enlighten the millennials about the importance of saving and investing starting at a young age. They need to teach the younger generations the benefits of starting to save in their twenties rather than in their forties. The goal should be to motivate the millennials to start investing, and when they do, the advisors will be waiting with open arms to begin building lasting relationships that will help the clients meet their financial needs. These companies must reach out to millennials to inspire them and inform them that with the help of the financial advisors, anyone has the potential to achieve the financial stability that every single person desires. The industry must be able to inspire the millennials to potentially utilize their technological skills to become more successful investors than ever before. We are in the midst of an exciting revolution that will change how consumers will conduct financial decision making as well as how financial institutions serve their clients. The impact of the changing consumer demographic and the disruptive technologies cannot be underestimated, by the year 2020, and beyond, we will witness a more efficient and better-trusted financial services industry.

Rolfe Winkler and Telis Demos (2016) in a WSU article state that Stripe, Inc., who utilizes their business software to help companies to take and track digital payments, will be valued at over $\$ 9.2$ billion. According to their article, Stripe, Inc. was already valued more generously than most U.S. "FinTech" startups such as Betterment Holdings, Inc. and Social Finance, Inc. Most of Stripe's volume is generated by online transactions, and it is estimated that fifty percent of all U.S. internet users have made a payment through a merchant using Stripe. This is amazing considering Patrick and John Collison - Irish brothers who both dropped out of college before graduating from MIT and Harvard respectively - founded it just six years ago. Recently the firm created Radar, which is a service incorporating transaction data to uncover fraudulent payments. If we add facial recognition technology to concepts like Radar, then safety can be assumed with an incredibly high rate of confidence.

Stripe is just one amazing example of a "FinTech" company that is altering the financial landscape, but there are many other startups, which are taking convenience and safety to the next level. John Rampton (2016) who is both an investor and entrepreneur talks about various "FinTech firms" which could be part of his Vision 2020. These various firms are altering the way and method of how money is changing hands, creating a much easier path to improve how transactions between two entities complete their business with each other. Some of the examples John Rampton list can be quite significant in changing the future financial landscape. Notable examples would be Bill.com which is a digital payment platform uniting businesses with banks and AVOKA which promises "Frictionless" digital sales and service. BillGuard is a mobile application which tracks your spending, and guards against fraud, while JUMIO Inc., permits small businesses to scan cards in real time, or to check on possible fraud. Transfer Wise, Inc. allows for the transferring of money abroad without the unnecessary bank fees. It is estimated that Transfer Wise can save you up to 90 percent, and the service is so popular with ex-patriots that even Richard Bronson has been reported to have invested in the firm. Some of the new investors are wanting to spend and send currency more quickly and efficiently, and if we incorporate upcoming technology like facial recognition technology, we can add the ultimate goal of safety.

There must be a transformation in the way financial advisors charge for their advice. According to Jason Zweig, you pay as little as .25 percent up to 2 percent or more annually on your assets managed. For less than 1 percent annually, you can construct your own portfolio of exchange-traded funds (ETFs) encompassing every conceivable worthwhile investment on the globe. In addition, online "robo-advisor" services will professionally manage ETF portfolios for you for less .25 percent or less.

Although you may need more advice on things other than baskets of assets (e.g., savings, managing debt, estate taxes, charitable giving, etc.), most financial advisors do not presently charge separately for 
it. As Jason Sweig states - your doctor doesn't automatically take a percentage of financial assets for keeping you well, nor does your accountant charge you a percent of your taxable income for preparing your return. Does your attorney charge you 1 percent of your wealth for drafting your will? Financial advisors should charge fees like everyone else does. As Mr. Sweig correctly states, only when financial advisors commence to transparently price their services, will the investor begin to know how valuable these services are.

\section{References}

1. Bankcorp Bank, Simple Online Banking with Automatic Budgeting and Savings. Available: https://www.simple.com/.

2. J. Berman, Where millennials go for financial advice. Wall Street Journal. Available: http://www.wsj.com/articles/where-millennials-go-for-financial-advice-1450062181

3. Capgemini Corporation, World Retail Bank Report 2013. Available: www.capgemini.com.

4. S. Chaudhuri, Ranking the biggest U.S. Banks: A new entrant in Top 5. Wall Street Journal. Available: http://blogs.wsj.com/moneybeat/2014/09/15/ranking-the-biggest-u-s-banks-a-new-entrant-in-top-5/tab/print/

5. Cloud Security Alliance, Available: https://cloudsecurityalliance.org/

6. Covestor, We invest. You invest with us. Why Covestor? Available: http://site.covestor.com/how-covestorworks/why-covestor

7. M. Dietz, S. Khanna, T. Olanrewaju and K. Rajgopal, Cutting through the noise around financial technology. McKinsey and Company. Available: http//www.mckinsey.com/industries/financial-services/ourinsights . 2016.

8. J. Donohue, M. Hooker, C. Lewis, and W. Pryor, The evolving role of technology in financial services. Vision, VIII.1: 8-20. Available: http://www.top1000funds.com/wp-content/uploads/2011/04/11-00330276_VISION_paper_TheEvolvingRoleTech.pdf

9. EToro, What is social trading? EToro Social Trading Comments. Available: <https://www.etoro.com/en/socialtrading/> 2014

10.Federal Reserve of St. Louis, (2014). Net savings as a percentage of gross national income. Available: https://research.stlouisfed.org/fred2/series/W207RC1A156NBEAU.

11.Federal Reserve of St. Louis, (2014). Real disposable personal income: Per capita. Available: https://m.research.stlouisfed.org/fred2/series/A229RX0.

12.A. Garg, Cloud computing for the financial services industry. n.d. Sapient. 2014, December 14.

13.Gartner, "Driving Business Transformation." Business Intelligence. 1 Jan. 2013. 14 Dec. 2014. Available; https://lobapplications.wordpress.com/category/technology/bi/.

https://lobapplications.files.wordpress.com/2014/06/gartner-top-finance-priorities.png?w $=650$

14.W. Gates, Brainy Quote. Xplore. Available: http://www.brainyquote.com/quotes/quotes/b/billgates390682.html. 2014, December.

15.F. Hobbs and N. Stoops, Population by age and sex for the United States: 1900-2000, Part A-9. U.S.Census Bureau, Census 200 Special Reports, Series CENSR-4. Demographic Trends in the 20th Century. Vol. 8, No. 3. 2002.

16.P. Hyde, A. Jain and S. Lyman, Wealthy, young, and ambitious: How banks can profitably serve the rising mass affluent. Available:

http://www.strategyand.pwc.com/global/home/what-we-think/reports-white-papers/article-display/wealthyyoung-and-ambitious 2013, October 4.

17.IBM Corporation, Cloud Computing. Available: http://www-935.ibm.com/services/multimedia/IBM_Future_of_Cloud_WEB.pdf 2014, December 14.

18.S. Kappagantula; and A. Kulkarni. Future of Image Technologies in Financial Services. A White Paper. External Document, InfosysLimited. 2015.

19.KPMY, LLC., KPMG Study: "Underserved" market represents opportunity for banks. 2011, June 2.

20.L. Kuykendall, Heirs take money and run-from financial advisors, Investment News. http://www.investmentnews.com/article/20111106/REG/311069982/heirs-take-money-and-run-from-financial advisers. 2011, November 6 . 
21.LearnVest. Available: https://www.learnvest.com/ 2014, December.

22.LendingClub.com. Innovation Transforms Lending, Available: https://www.lendingclub.com/public/how-peerlending-works.action 2014.

23.M. Lynch, The financial services industry in 2030. Available: http://wealthmanagement.com/viewpoints/financial-services-industry-2030. 2013, October.

24.P. Mell and T.Grance, (2011, September). The NIST definition of cloud computing. National Institute of Standards and Technology. 2011, September. Special publication. 2014, December 14.

25. Moneychimp, Compound annual growth rate (annualized return) Available: http://www.moneychimp.com/features/market_cagr.htm. 2014.

26.Motif Investing, Inc., Available: https://www.motifinvesting.com. 2014.

27.H. Peterson, The 12 jobs most at risk of being replaced by robots. Business Insider. Business Insider, Inc. Available: <http://www.businessinsider.com/jobs-at-risk-of- being-replaced-by-robots-2014-3>. 2014, March 12.

28.Pew Research Center. (2014, January). Social networking fact sheet. Available: http://www.pewresearch.org/.

29.L. Philios, Tear down your barriers to saving-and cross the bridge to financial success. Available: http://www.saveandinvest.org/financialbasics/saving/p125938 2014, December 14.

30.J. Pucella, and D. Beattie. Outlook - North American banks. Moody's Investors Service. Available: https://www.moodys.com/researchandratings/market-segment/financial-institutions/-

/005001/4294966440\%204294965363\%204294965746/4294967230/0/0/-/0/-/-/-/-1/-/-/-/en/global/pdf/-/rra 2014, December.

31.J. Rampton, 22 Financial Technology Startups You Need to Know. Available: http://wwws.inc.com/johnrampton/topfintechstartups

32.S. Rattner, Saving young people from themselves. New York Times. Available: www.nytimes.com/2014/04/13/opinion/sunday/saving-young-people-from-themselves.html?_r=0 2014, April 13.

33.A. Reichert, Smartphones changing the way millennials bank." The Financial Brand. Available: http://thefinancialbrand.com/42513/mobile-banking-millennials-photo- research/. 2014, September 25.

34.J. Skan, The boom in Fintech Investment. Accenture. Available: http://www.accenture.com/Microsites/fsinsights/capital-markets-uk/Documents/Accenture-Global-Boom-inFintech-Investment.pdf. 2014, December.

35.SAP News, New survey findings from SAP and Ovum reveal high cloud adoption in the financial services industry. Available: http://www.news-sap.com/new-survey-findings-sap-ovum-reveal-high-cloud-adoptionfinancial-services-industry/2014, December.

36.A. Tergesen, Robo Advisor lowers investing minimum. Weekend Investor, Wall Street Journal. Available: http://www.wsj.com/articles/automated-robo-adviser-lowers-its-investment-minimum-1447855380. 2015, Nov.

37.U.S. Bureau of Economic Analysis, (2012, March). Alternative measures of personal saving. Available: http://www.bea.gov/scb/pdf/2012/03\%20March/0312_personal_saving.pdf 2012, March.

38.J. Van Bergen. Paying your investment advisor - fee or commissions? Investopedia. 2014, December 14.

39.R. Winkler and T. Demos, Wall Street Journal. Available: http://www.wsj.com/articles/stripes-valuation-nearlydoubles-to-9-2-billion-1480075201 2016, November 25.

40.World Bank Group, The. (2014, December). GNI per capita, PPP (current international \$). Available: http://data.worldbank.org/indicator/NY.GNP.PCAP.PP.CD 2012, March.

41.Zogby Polls, Zogbyanalytics.com/news.

42.J. Zweig, Why you're paying too much in advisory fees. Wall Street Journal. 2015, June 20-21. 